\title{
ІПСАТИВНА МЕТОДИКА В ДОСЛІДЖЕННІ ШЛЮБНО- СІМЕЙНИХ ПРАКТИК ПАРТНЕРСТВА ТА БАТЬКІВСТВА
}

\author{
УДК:159.924.7 - 055.52+ 159.9.018.2:316.614.5 - 058.837
}

\section{Яиина Олена Федорівна}

Кандидат педагогічних наук, дочент, дочент кафедри психології Державного вищзого навчального закладу «Ужгородський національний університет», м. Ужгород (Украӥна)

\begin{abstract}
Анотація. Експериментальні дослідження семантики свідомості виявляють індивідуальні системи значень в індивідуальній свідомості, через призму яких $і$ відбувається сприйняття суб'єктом світу, самого себе та інших. В умовах постмодерну увага дослідників поширюється на опис представлених в иій реальності соиіально-психологічних практик як способів життєтворення, щуо пов'язані з власною інтерпретацією сочіальності $i$ конструюванням особистісних ідентичностей, як иче легітимується постмодерном. Зміни, щзо відбуваються в ПШСПБ (практиках илюбно-сімейного партнерства та батьківства), закономірно трансформують уявлення про сім'ю, илюб, партнерство та батьківство, а тому потребують іншого наукового пояснення, щуо не знайшло ще свого відображення в психології ciм'i.

Кластерний аналіз підтвердив припущення про обумовленість постмодерних трансформацій ПШСПБ соиіально-психологічними феноменами, пов'язаними зі змінами смислів у структурно-функціональній організації практик та множинністю ідентичності як ідентифікаційної моделі рольової поведінки в умовах іншої соичіальності. Виявлено, щзо конструйовані практики партнерства $і$ батьківства мають різну функиіональність для подружжя/партнерів, вирізняються як смислами, изіннісними орієнтаціями щзодо їх утворення, так і множинністю представлених ідентичностей. 3 метою реконструкції структури уявлень респондентів про рольові ідентифікації у побутових ситуаціях, перспективним розглядаємо дослідження психосемантичного простору рольових позицій, пов'язаних із практиками партнерства та батьківства.
\end{abstract}

Ключові слова: ідентичність, дискурс, структура уявлень, роль.

В умовах постмодерну увага дослідни- рення, що пов'язані з власною інтерпретацією ків поширюється на опис соціально- соціальності і конструюванням особистісних психологічних практик як способів життєтво- ідентичностей, як це легітимується постмоде- 
рном. Вибір методики дослідження було визначено на користь іпсативної методики тестування, в котрій, за висновками дослідників, мінімізовано «ефект соціальної бажаності» як нормативного припису. Завдання полягає в аналізі результатів опитувальника, що відтворюють реконструкції структури уявлень рольових ідентифікацій у повсякденних практиках партнерства та батьківства.

Було виокремлено 8 груп об'єктівдескрипторів. За допомогою кластерного аналізу кінцеву структуру кластерів, що відповідає обраному критерію оптимальності утворюють чотири кластери: «ідентичність», «функціональність», «ціннісні орієнтації», «інституціональні зміни». Кластерний аналіз підтвердив припущення про обумовленість постмодерних трансформацій ПШСПБ соціально-психологічними феноменами, пов'язаними зі змінами смислів у структурнофункціональній організації практик та множинністю ідентичності як ідентифікаційної моделі рольової поведінки в умовах іншої соціальності. Виявлено, що конструйовані практики партнерства і батьківства мають різну функціональність для подружжя/партнерів, вирізняються як смислами, ціннісними орієнтаціями щодо їх утворення, так і множинністю представлених ідентичностей.

Плюралістичний світ постмодерну надає особистості можливість вибору, покладаючись на почуття довіри/недовіри до існуючих систем, інституцій, інших індивідів. Тому осо- бистість епохи постмодерну сприймає світ через переконаність у вичерпаності по відношенню до себе будь-яких універсалій, зміні наративів, що претендують на панування системи поглядів. Відтак, людина інформаційного суспільства спрямовує себе на активний пошук можливих альтернатив, до яких відчуває «активну довіру» (Е. Гідденс).

Експериментальні дослідження семантики свідомості виявляють індивідуальні системи значень в індивідуальній свідомості, через призму яких і відбувається сприйняття суб'єктом світу, самого себе та інших. В умовах постмодерну увага дослідників поширюється на опис представлених в цій реальності соціально-психологічних практик як способів життєтворення, що пов'язані з власною інтерпретацією соціальності і конструюванням особистісних ідентичностей, як це легітимується постмодерном. Зростання уваги до одиничного, пріоритетність особистого, індивідуального, цінність кожного в усій його різноманітності - все це не може не відобразитися у поглядах на сім'ю та іï цінності [2,c.3-12]. Аналізуючи проблеми сім'ї в епоху постмодерна, Т. В. Савінкова, обгрунтовано стверджує, що в епоху культурного розлому, коли все стає конвенціональним, перестає виражати зрозумілі смисли і укладатися в прийняті дефініції, інститут сім'ї не може зберігати минулі соціокультурні параметри [3,c.66-74]. Насправді, особливістю сучасного розвитку інститутів сім'ї та шлюбу $€$ їхня нелінійність, коли вже не спостерігаєть- 
ся такого тісного зв'язку і спадкоємності між поколіннями, а світосприймання стає поліфонічним. На думку Д. В. Іванова, соціальноісторична реальність, інституціональний устрій якої розглядали П. Бергер і Т. Лукман, в останні десятиліття перетворюється в ефемерну, нестабільну. В ній сутність людини відчужується не в соціальну реальність, а у віртуальну. Власне, віртуальна реальність, на думку Д. В. Іванова, є тим простором, в якому вмирають артефакти традиційної культури і народжуються нові [1,с.19-20]. Зміни, що відбуваються в ПШСПБ (практиках шлюбносімейного партнерства та батьківства), закономірно трансформують уявлення про сім'ю, шлюб, партнерство та батьківство, а тому потребують іншого наукового пояснення, що не знайшло ще свого відображення в психології сім’і.

Нас цікавлять насамперед не вирішені раніше частини загальної проблеми. Завдання психологічного вивчення індивідуальної свідомості про опосередкований вплив соціальної реальності на поведінку суб'єктів змушують шукати й інші технології тестування, альтернативні традиційним опитувальникам стосунків в сім'ї, докладно представленим в «Енциклопедії діагностики» (внутрішні проблеми сімейної пари, вибори партнера, дитячо-батьківські стосунки, тощо). Вибір було визначено на користь іпсативної методики тестування, в котрій, за висновками дослідників, мінімізовано «ефект соціальної бажаності» як нормативного припису. Поняття «іпсативний» має латинський корінь «ipse», що означає «сам/особисто». В теорії психологічного вимірювання зазначений термін використовують для означування тих випадків, коли результати діагностики кожного досліджуваного слугують вимірювальним еталоном для самого себе. Іншими словами, це означає, що в процесі аналізу результатів тестування використовуються не зовнішні еталони-норми, а система суб'єктивних порівнянь і виборів кожного досліджуваного. Іпсативне оцінювання використовують по відношенню до тих вимірювань, в котрих респонденти можуть свідомо здійснювати вибір 3-поміж запропонованих варіантів, враховуючи зв'язок із системою своїх уподобань. Логіка створення іпсативної методики це формат відповідей у ситуації вимушеного вибору, де досліджувані мають обирати варіант із переліку запропонованих тверджень, що в більшій мірі співпадають $з$ його уявленнями або менш за все співпадають. Здійснюючи «вимушені вибори», респонденти охоплюються когнітивним процесом.

Відтак, завдання статті полягає в аналізі результатів опитувальника, що відтворюють реконструкції структури уявлень рольових ідентифікацій у повсякденних практиках партнерства та батьківства.

Методом побудови суб' єктивних семантичних просторів було доведено, що індивідуальні системи значень впливають на вибори і конструювання практик партнерства та бать- 
ківства й конституювання в них множинних ідентичностей.

Аналіз Інтернет-джерел 3 досліджуваної нами проблематики дозволив зібрати чимало текстових висловлювань користувачів, що слугували емпіричним матеріалом для укладання іпсативної методики, яка отримала назву «Конфігурації особистісних виборів приватного життя (КОВПЖ)». Структуру методики утворюють 40 пар суджень, в кожному 3 яких респондент має обрати одне 3 двох. В твердженнях містяться способи реагування i поведінки, з якими респондент може погодитись або ні, здійснюючи вибір між двома альтернативами. Жодне альтернативне твердження може не відображати справжніх вподобань респондента, і в цьому вбачається певна гра словесних конструктів. Проте, сконструйовані за іпсативним принципом, вони дозволяють долати тенденцію давати соціально бажані відповіді, позаяк обидва судження зумисне підібрано у такий спосіб, щоби рівень соціальної бажаності та особистісний вибір були збалансовані. Надані розгорнуті формулювання тверджень виражають різні сторони практик шлюбно-сімейного партнерства та батьківства. Співставляючи їх попарно, респондент обирає між двома варіантами той, що в більшій мірі відповідає його розумінню змісту висловлювань.

Об'єктом дослідження були особи різного віку (від 18 до 59 років: середній вік респондентів - 25 років), різного сімейного ста- ну: одружені, розлучені, у стосунках; різні за освітою та професійною діяльністю. Такий культурний фон досліджуваних дозволяє припустити, що отримана емпірична інформація, буде віддзеркалювати уявлення респондентів, асоційовані 3 полідискурсивним соціальнокультурним середовищем, як от: нормативний дискурс традиційних практик сім’ї та шлюбу чи текучий дискурс сучасних практик партнерства та батьківства. Утворена способом рандомізації, представлена вибірка є репрезентативною. Вибіркова сукупність своїми основними параметрами цілком може сприйматися як частина об'єктів генеральної сукупності, а отримані в процесі дослідження дані, можуть поширюватися на всю генеральну сукупність. Для аналізу масиву даних було обрано кластерний аналіз. Метою кластерного методу обробки було з'ясування внутрішньої структури даних, придатних для подальшого аналізу, де кожен кластер складається зі схожих ситуацій, а ситуації виявлених кластерів істотно відрізняються між собою. Під структурою кластерів розуміється склад окремих кластерів та їх взаємне розташування у багатомірному просторі.

Процедура здійснення кластерного аналізу полягала в обрахуванні головної числової характеристики вибірки - середнього значення за кожним дескриптором. Всі об'єкти спостереження розглядалися як самостійні «моно кластери», утворені з одного елемента. Далі було обрано метод деревоподібної кластериза- 
ції: пошук міри відстаней (distance) між усіма об'єктами вибірки за допомогою одинарного зв'язку способом Евклідової відстані (Euclidean distance). Це найуживаніша міра відстані між об'єктами, яка являє собою геометричну відстань між об'єктами у багатомірному просторі. Після обчислення відстаней почався процес агломерації: кластер утворює та пара, для котрої відстань виявилася найменшою. За допомогою методу деревоподібної кластеризації побудовано ієрархічне кластерне дерево (hierarchical tree), що має вигляд горизонтальної деревовидної діаграми (horizontal hierarchical tree, vertical icicle plot) (Рис. 1).

На рисунку чітко видно утворену кластерну структуру, що в термінах кластерів об'- єктів, схожих між собою, відображає ієрархічне дерево з різними гілками (кластерами). Горизонтальні вісі дендограми представляють відстані об'єднання (linkage distance), вісі міжкластерної відстані, а на вертикальній вісі відмічено номери об'єктів (дескрипторів), використаних в аналізі. Візуальний аналіз припускає «обрізання» дерева на оптимальному рівні схожості елементів вибірки. У нашому випадку в умовному першому кластері (утвореному із п’яти шкал), який ми позначили на графіку, відстані між показниками розподілилися так: $\operatorname{Var} 1(0,93)$ - Var25(0,94) - Var12(0,82) - Var9 $(0,73)$ - Var17(0,74). Відтак, за середніми показниками, вірогідно, може змінитися і кількість кластерів з їхнім наповненням. Середнє для кожного кластера вказує, наскільки кластери

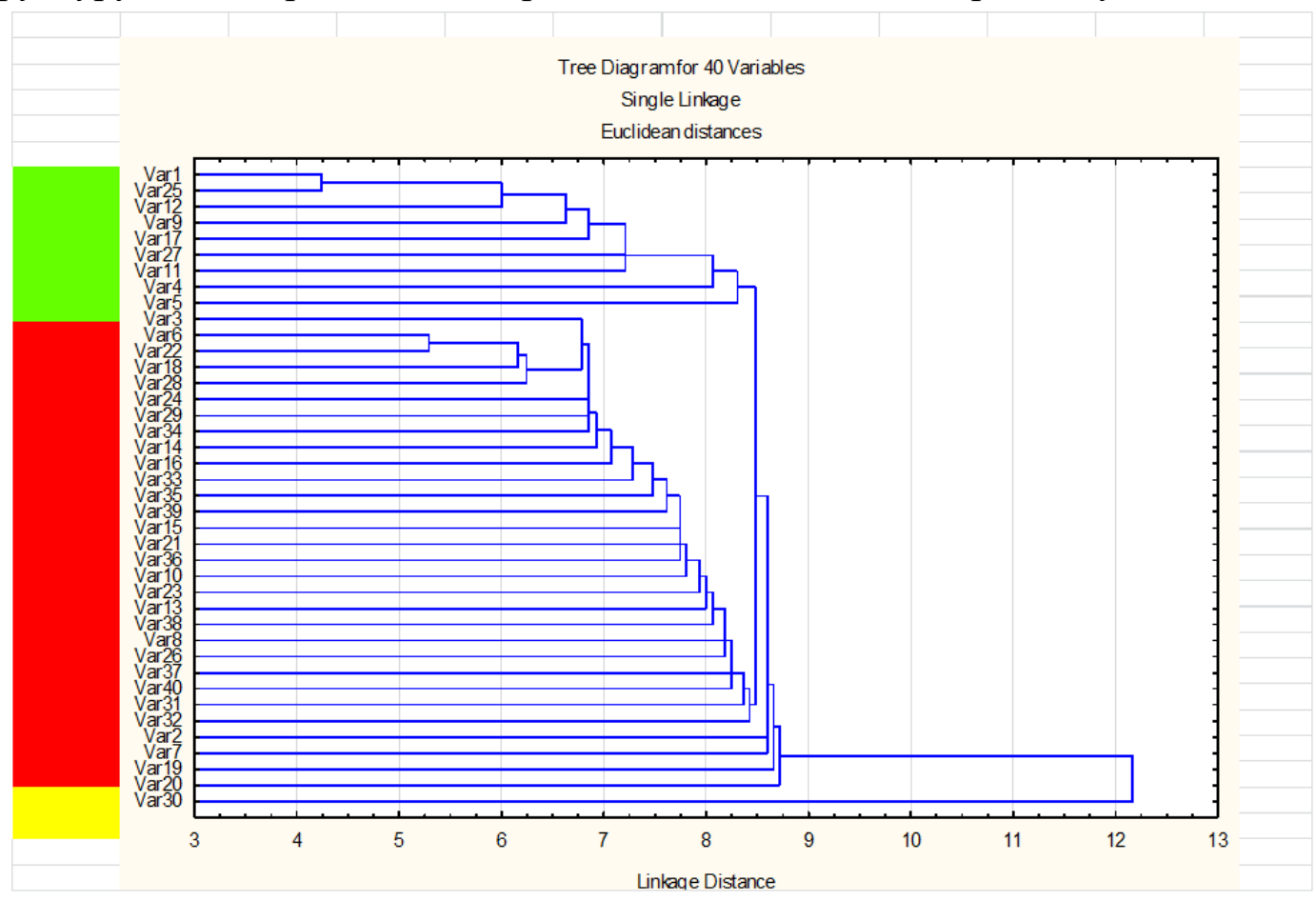

Рис. 1. Ієрархічне кластерне дерево «Конфігурацій особистісних виборів приватного життя (КОВПж)» 
схожі між собою і можуть бути об'єднані певним алгоритмом у кластер. Використовується метод ближнього сусіда (single linkage (nearest neighbour)), коли відстань між двома кластерами визначається відстанню між двома найбільш близькими об'єктами в різних кластерах, і до вже існуючого кластера приєднується інший. Умовою приєднання $є$ та сама міра схожості з приєднаним об'єктом. Обчислені об'єкти мають незначну різницю у відстані, тому на дендограмі ця процедура нагадує каскад 3 кластерів. Інтерпретування отриманої в результаті кластерного аналізу дендограми показує міру близькості окремих об'єктівдескрипторів і кластерів та графічно демонструє послідовність їхнього об'єднання. Кількість рівнів дендограми відповідає числу кроків злиття/розділення кластерів.

Першу групу об’єктів-дескрипторів об'єднує розуміння цінності шлюбу як можливості розвитку для кожного з подружньої пари. Наголошується на однаковості думок, поглядів, переконань подружжя та вмінні домовлятися. Високі середні показники об'єктів Var25 та Var22 можуть означати актуальність батьківства та поєднання материнства і жіночності.

Другу групу утворюють об'єкти [Var12 $(0,82), \operatorname{Var} 6(0,84)]$, в котрих смисл спільного життя у тому, щоби залишатися вільними у стосунках і незалежними від офіційної відмітки в паспорті.

Третю групу поєднує розуміння відпо- відальності за власний вибір, спільність цілей і завдань: будь то офіційний шлюб чи громадянський, чи материнська сім'я.

Четверта група відтворює уявлення про функціональність стосунків між чоловіком та жінкою. Для одних це пов'язано із побутовими зручностями, матеріальними вигодами, емоційним комфортом, для інших - із особистою свободою.

П'ята група об'єднує вислови, в яких обговорюються смисли спільного життя чоловіків і жінок, цінність котрих визначається у «житті для себе», заради дітей, у самоствердженні, професійному зростанні

Шоста група утворена на обговоренні різних ціннісних пріоритетів у практиках партнерства, серед яких освіта, кваліфікація, кар'єра, егалітарні стосунки між партнерами, побутовий і емоційний комфорт, подружній статус, почуття одне до одного.

В сьомій групі об'єкти поєднуються за висловами про чоловічі та жіночі стосунки, що пов'язані з господарськими обов'язками, тримаються на почутті спільності: майна, побуту, дітей, об'єднані почуттями любові та очікуванням щастя 3 коханою людиною, прагненням до самореалізації.

Восьму групу об'єднують міркування про характер інституціональних засад шлюбу, що виявляються у твердженнях про шлюб як альтернативу самотності, чи про те, що шлюб не гарантує виконання кожним із подружжя моральних, матеріальних зобов'язань, що гро- 
мадянський шлюб є інший, а не гірший вибір.

Здійснений змістовий опис за середніми показниками дозволяє, використовуючи метод повного зв'язку, об'єднати близькі за характеристиками об'єкти у кластери. На дендограмі чітко виділяються чотири кластери, утворені шляхом об'єднання. Перший такий кластер утворений об'єднанням монокластерів [Var1 $(0,93), \operatorname{Var} 25(0,94), \operatorname{Var} 22(0,96)] 3$ [Var 12(0,82), Var6 $(0,84)]$ та [Var27 $(0,69), \operatorname{Var} 11(0,72), \operatorname{Var} 9(0,73), \operatorname{Var} 17(0,74)]$, відстань між групами складає приблизно 0,27. Сукупно висловлювання відтворюють зміст, в якому проглядається схема процесу конструювання ідентичностей. В зміненій соціальній реальності індивід осмислюючи/ переосмислюючи світ, інших і самого себе, створює індивідуальний семантичний простір, в якому розміщуються, впорядковуються та класифікуються суб'єктивні образи об'єктів [Артем'єва, Петренко, Шмельов], які мають визначальне значення для конструювання поліфонії практик і конституювання в них ідентичностей. Надаючи індивідуального значення цінностям, функціям, ролям у сконструйованих практиках партнерства та батьківства, індивід у такий спосіб створює свій світ, в якому визначає відношення значимості i здатність до самовизначення, самопізнання, самотворення, самовідтворення й самоздійснення.

Другий кластер утворюють об'єкти [Var4 (0,60), Var5 (0,54),Var7 $(0,57), \operatorname{Var} 19$
$(0,58), \operatorname{Var} 20(0,53)]$, за змістом котрих вбачаємо зменшення функціональної універсальності шлюбно-сімейних практик, що супроводжується змінами в уявленнях про структурно-рольову організацію співжиття чоловіків і жінок.

Третій кластер утворюють найбільші за кількістю об'єктів монокластери - [Var2 $(0,42), \operatorname{Var} 37 \quad(0,43), \operatorname{Var} 40 \quad(0,48), \operatorname{Var} 31$ $(0,47), \operatorname{Var} 32 \quad(0,42), \operatorname{Var} 38 \quad(0,42)], \quad$ [Var21 $(0,30), \operatorname{Var} 35 \quad(0,33), \operatorname{Var} 15 \quad(0,32), \operatorname{Var} 36$ $(0,38), \operatorname{Var} 10 \quad(0,37), \operatorname{Var} 23 \quad(0,36), \quad \operatorname{Var} 13$ $(0,35)$, Var8 $\quad(0,38), \operatorname{Var} 26 \quad(0,38)] \quad$ та $\quad[\operatorname{Var} 3$ $(0,21), \operatorname{Var} 24 \quad(0,25), \operatorname{Var} 29 \quad(0,27), \quad$ Var14 $(0,25), \operatorname{Var} 16 \quad(0,26), \operatorname{Var} 33 \quad(0,24), \operatorname{Var} 30$ $(0,25), \operatorname{Var} 34(0,24), \operatorname{Var} 39(0,29)]$, відстань між якими складає приблизно 0,21. В цьому кластері відтворено уявлення про пріоритетність множини індивідуальних цінностей.

Четвертий кластер утворюють об'єкти [Var18 $(0,19), \operatorname{Var} 28(0,16)]$, зміст яких вказує на інституціональні зміни шлюбно-сімейних практик.

Міжкластерна відстань, як видно з графіка, мінімальна, за виключенням відстані між 1 та 4 кластерами, що складає 0,8. Відтак, групи об'єктів було об'єднано у кластери за певним алгоритмом. Отримані об'єднання за сукупністю характеристик увійшли, як показано в дендограмі, до чотирьох кластерів, що отримали назви: «ідентичність», «функціональність», «ціннісні орієнтації», «інституціональні зміни». Вони визначають 
кінцеву структуру кластерів (склад монокластерів та їхнє розташування у багатомірному просторі), що задовольняє обраному критерію оптимальності. Звертаємо увагу, що мінімальний розмір мають кластери «функціональність» та «інституціональні зміни», більшим є кластер «ідентичність». Тоді як кластер «ціннісні орієнтації» є найбільшим за розмірами, що дозволяє говорити про його максимальну компактність, щільність (density), а відтак і мінімальну дисперсію (variance) відстані від центру кластера до окремих його відрізків. Кластер «інституціональні зміни» констатує максимальну дисперсію відстані, отже він є більш розщепленим. Відмічаємо його часткове перекриття кластером «ціннісні орієнтації», таке саме перекриття спостерігається і по відношенню до кластера «функціональність».

Таким чином, за допомогою методу кластерної обробки даних було виявлено внутрішню структуру даних, яку утворюють кластери: «ідентичність», «функціональність», «ціннісні орієнтації», «інституціональні зміни», що є тими соціально-психологічними феноменами, з якими пов'язані трансформації ПШСПБ.

Нестандартизований характер якісного дослідження надає можливість респондентам вільно висловлюватися. Отримані у такий спосіб вільні дані допомагають розкривати смисли конструйованих/реконструйованих практик та утворених в них ідентичностей. Кластерний аналіз підтвердив припущення про обумовленість постмодерних трансформацій ПШСПБ соціально-психологічними феноменами, пов'язаними зі змінами смислів у структурнофункціональній організації практик та множинністю ідентичності як ідентифікаційної моделі рольової поведінки в умовах іншої соціальності. Виявлено, що конструйовані практики партнерства і батьківства мають різну функціональність для подружжя/партнерів, вирізняються як смислами, ціннісними орієнтаціями щодо їх утворення, так і множинністю представлених ідентичностей. Відтак, множинність практик продукує появу і нових функцій, диференціюючи практики за їхньою функціональністю, що відображається у переосмисленні та зміні системи координат сімейних та індивідуальних ціннісних орієнтацій, гендерних ролей, та веде до того, що сім'я, шлюб, батьківство як соціальні інституції втрачають колишню взаємообумовленість.

3 метою реконструкції структури уявлень респондентів про рольові ідентифікації у побутових ситуаціях, перспективним розглядаємо дослідження психосемантичного простору рольових позицій, пов'язаних із практиками партнерства та батьківства.

\section{Перелік використаних джерел:}

1. Иванов Д. В. Виртуализация общества. СПб.: «Петербургское Востоковедение», 2000. - 96 с., с.1920.

2. Рябикина 3. С., Тиводар А. Р. Личностная идентич- 
ность в супружеских отношениях // Человек. Сообщество. Управление. - 2011, №4, - С.3-12.

3. Савинкова Т. В. Институт семьи в эпоху постмодерна // Настоящее и будущее социальных технологий. Социальные технологии XXI века: инновации и реальность : мат-лы IX междунар. науч.-практ. конф. - СПб. : Изд-во СЗИ РАНХиГС, 2012. - С. 66-74.

\section{References (Transliteration):}

1. Ivanov $\quad$ D. $\quad$ V. Virtualizatsiya obschestva. SPb.: «Peterburgskoe Vostokovedenie», 2000. - 96 s., s.19-20.

2. Ryabikina Z. S., Tivodar A.R. Lichnostnaya identichnost v supruzheskih otnosheniyah // Chelovek. Soobschestvo. Upravlenie. - 2011, \#4, - S.3-12.

3. Savinkova T. V. Institut semi v epohu postmoderna // Nastoyaschee i buduschee sotsialnyih tehnologiy. Sotsialnyie tehnologii XXI veka: innovatsii i realnost : matlyi IX mezhdunar. nauch.-prakt. konf. - SPb. : Izd-vo SZI RANHiGS, 2012. - S. 66-74.

\section{Yatsyna Olena}

Candidate of Pedagogic Science, Assistant Professor of the Department of Psychology, Uzhgorod State National University, Uzhgorod (Ukraine)

\section{IPSATIVE METHODOLOGY IN THE STUDY OF MARRIAGE AND FAMILY PRACTICES OF PARTNERSHIP AND PARENTHOOD}

\author{
ABSTRACT \\ Experimental researches on the semantics \\ of consciousness show individual systems of \\ meanings in individual consciousness, through \\ the light of which a subject perceives the world, \\ himself /herself and others. In postmodern times, \\ scholars draw their attention to the description of \\ social and psychological practices presented in
}

this reality as ways of life-construction, connected with its interpretation of sociality and the search for personal identities, as it is legitimized by postmodernism. Changes in marriage and family practices of partnership and parenthood naturally transform the perception of a family, marriage, partnership and parenthood, and therefore require another scientific explanation that has not yet been reflected in the psychology of the family.

The choice of the research methodology was made in favour of the ipsative approach, which, according to scholars, minimizes the «effect of social desirability» as a normative prescription. The task is to analyse the questionnaire's results, which reflect the structure reconstruction of role identities representations in partnership and parenthood everyday practices. According to the results we have distinguished 8 groups of object-descriptors. They determine the final structure of the clusters, which corresponds to the chosen optimality criterion.

The cluster analysis confirmed the assumption that postmodern transformations of marriage and family practices of partnership and parenthood are conditional on social and psychological phenomena, connected with changes of meanings in the structural and functional setup of practices as well as with multiplicity of identity as an identification model of role behaviour in conditions of another sociality. The study has shown that formed partnership and parenthood practices have different functionality for spouse / 
partners and they are distinguished both by meanings, value orientations on their creation, and the multiplicity of identities presented.

In order to reconstruct the structure of respondent's representations about role identifications in everyday situations, we consider promising the idea of studying the psycho-semantic space of role positions connected with partnership and parenthood practices.

Key words: identity, discourse, structure of representations, role.

\section{Яцына Елена Федоровна}

Кандидат педагогических наук, доиент, доиент кафедры психологии ГВУЗ «Ужгородский национальный университет»., г. Ужгород (Украина)

\section{ИПСАТИВНАЯ МЕТОДИКА В ИССЛЕДОВАНИИ БРАЧНО-СЕМЕЙНЫЕ ПРАКТИК ПАРТНЕРСТВА И ОТЦОВСТВА}

Аннотация. Экспериментальные исследования семантики сознания определяют индивидуальные системы значений в индивидуальном сознании, через призму которых происходит восприятие субъектом мира, себя, других. В условиях постмодерна внимание исследователей распространяется на описание представленных в этой реальности социальнопсихологических практик как способов жизнеконструирования, которые связаны с собственной интерпретацией социальности и конструированием личностных идентичностей, как это легитимируется постмодерном. Изме- нения, которые происходят в практиках брачно-семейного партнерства и родительства, закономерно трансформируют представления о семье, браке, партнерстве и родительстве, а поэтому требуют другого научного объяснения, которое еще не отражено в психологии семьи.

Выбор методики исследования был определен в пользу ипсативной методики, в которой, по выводам исследователей, минимизирован «эффект социальной желательности» как нормативного предписания. Задание состояло в анализе результатов опросника, которые воссоздают реконструкции структуры представлений ролевых идентификаций в повседневных практиках партнерства и родительства.

По итогам было определено 8 групп объектов-дескрипторов. С помощью кластерного анализа четко выделяются четыре кластера, которые названы: «идентичность», «функциональность», «ценностные ориентации», «институциональные изменения». Они определяют конечную структуру кластеров, которые отвечают избранному критерию оптимальности.

Кластерный анализ подтвердил предположение об обусловленности постмодерных трансформаций практик партнерства и родительства социально-психологическими феноменами, связанными с изменением смыслов в структурно-функциональной организации практик и множественностью идентичностей 
как идентификационной модели ролевого поведения в условиях другой социальности. Определено, что конструированные практики партнерства и родительства имеют разную функциональность для супругов/партнеров, отличаются как смыслами, ценностными ориентациями относительно их создания, так и множественностью представленных идентичностей.

С целью реконструкции представлений респондентов о ролевой идентификации в бытовых ситуациях, перспективным рассматриваем исследование психосемантического пространства ролевых позиций, связанных с практиками партнерства и родительства.

Ключевые слова: идентичность, дискурс, структура представлений, роль. 